\title{
Zoeal Stages of Lysmata vittata (Decapoda: Caridea: Hippolytidae) Reared in the Laboratory
}

\author{
Hoi Jeong Yang ${ }^{1, *}$ and Chang Hyun Kim² \\ ${ }^{1}$ Gwacheon National Science Museum, Gwacheon 427-060, Korea \\ ${ }^{2}$ Department of Biology, Pusan National University, Busan 609-735, Korea
}

\begin{abstract}
Nine zoeal stages of Lysmata vittata (Stimpson, 1860) are described from laboratory-reared material. The ornamentation of the carapace and the fifth abdominal somite readily distinguish the first zoeas of $L$. vittata from the two previously known first larvae of Lysmata (L. anchisteus and L. seticaudata). Larval characters of the genus Lysmata are summarized. The setation of 1,2,3(6) on the basis of the second maxilliped indicates that Lysmata is closely related to Exhippolysmata.
\end{abstract}

Keywords: zoeas, Lysmata vittata, Exhippolysmata, Hippolytidae

\section{INTRODUCTION}

Four species of Lysmata had been reported in the East Asian waters: L. amboinensis (De Man, 1888); L. dentata (De Haan, 1844); L. kükenthali (De Man, 1902); and L. vittata (Stimpson, 1860) (see Hayashi, 1994). Recently, two further species of L. ternatensis De Man, 1902 and L. zacae Armstrong, 1941 are known from Japanese waters (see Debelius, 2001). Six species of Lysmata, thus have been reported from the East Asian waters, among which L. amboinensis and L. vittata are known from Korean waters (Yang and Kim, 2006a). L. vittata is found in the littoral zone down to 54 meters (Chace, 1997; Debelius, 2001).

Larvae of Lysmata have been described for three species so far: L. anchisteus Chace, 1972, laboratory-reared larvae described by Knowlton and Alavi (1995) from Bahama; $L$. seticaudata (Risso, 1816), larvae collected from plankton material or reared in the laboratory by Caroli (1918), Kurian (1956), Bourdillon-Casanova (1960), and Calado et al. (2004) from European waters; and L. vittata, laboratory-reared zoeas by Kuriyan (1951) and Pillai (1966) from Indian waters. In 1951, Kuriyan, under the name Hippolysmata vittata Stimpson, 1860, provided the larval description of the first zoeas of L. vittata, but no figure was given. Subsequently, in 1966, Pillai also using the name $H$. vittata, described the first three zoeal stages of L. vittata. However, no descriptions of the maxillule and maxilla were provided, and the description of the first to third maxillipeds was incomplete.

The present study describes nine zoeal stages of $L$. vittata in detail, compares the morphological characteristics of the

*To whom correspondence should be addressed

Tel: 82-2-3677-1365, Fax: 82-2-3677-1369

E-mail: hjyang@mest.go.kr first zoeas of $L$. vittata with those of $L$. anchisteus and $L$. seticaudata for which larvae are known, and summarizes larval characteristics of the genus Lysmata.

\section{MATERIALS AND METHODS}

On 26 May 1997, four ovigerous females of Lysmata vittata were collected from an oyster raft culture in Sangju, southern Korea $\left(34^{\circ} 43^{\prime} 00^{\prime \prime} \mathrm{N} 127^{\circ} 59^{\prime} 30^{\prime \prime} \mathrm{E}\right)$. More than 300 larvae hatched from one female. After hatching occurred, 200 larvae were reared individually at constant seawater temperature of $25^{\circ} \mathrm{C}$, using methods described by Yang (2009). They were fed daily with freshly hatched Artemia nauplii. Larvae of each zoeal stage were fixed and preserved in $7 \%$ neutral Formalin. Measurements and setal counts on appendages were based on ten specimens for each stage. Examination of dissected appendages and drawings were made using a Nikon FX II microscope with the aid of a camera lucida. Setal armature on appendage was described from proximal to distal segments. Carapace length (CL) was measured from postorbital margin to posteromedian border of the carapace. The chromatophore pattern was determined by observation on live larvae. The first zoeal stage is described in detail. Only the main differences from the previous stages are provided for the subsequent stages.

\section{RESULTS}

Nine zoeal stages were obtained.

First zoea (Figs. 1A, B, 2).

Duration. 3-5 days. 


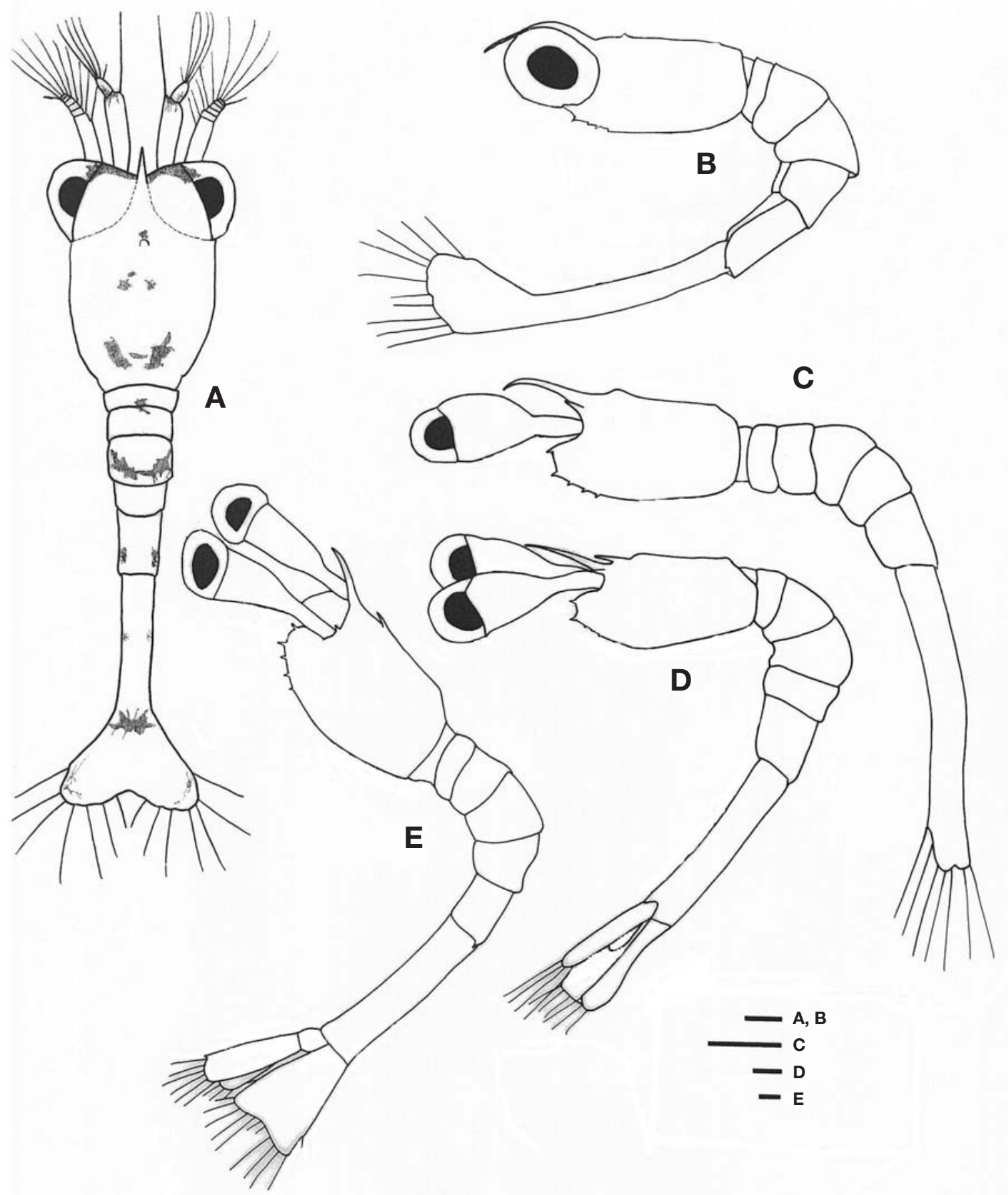

Fig. 1. Habita of Lysmata vittata (Stimpson, 1860). A, first zoea, dorsal view; B, first zoea, lateral view; C, second zoea, lateral view; $D$, third zoea, lateral view; E, fourth zoea, lateral view. Thoracic appendages omitted in B-E. Scale bars $=0.1 \mathrm{~mm}$.

Size. CL $0.34(0.33-0.37) \mathrm{mm}$.

Carapace (Fig. 1A, B). Rostrum simple, tapering terminally, reaching to half length of peduncle of antennule in dorsal view; anterior dorsomedian papilla present; supraorbital and antennal spines absent; anteroventral margin with pterygo- stomian spine and 3 denticles; eyes sessile, without terminal papillae.

Antennule (Fig. 2A). Peduncle with long plumose seta, base of peduncle swollen; inner flagellum not differentiated; outer flagellum with 4 aesthetascs and plumose seta. 


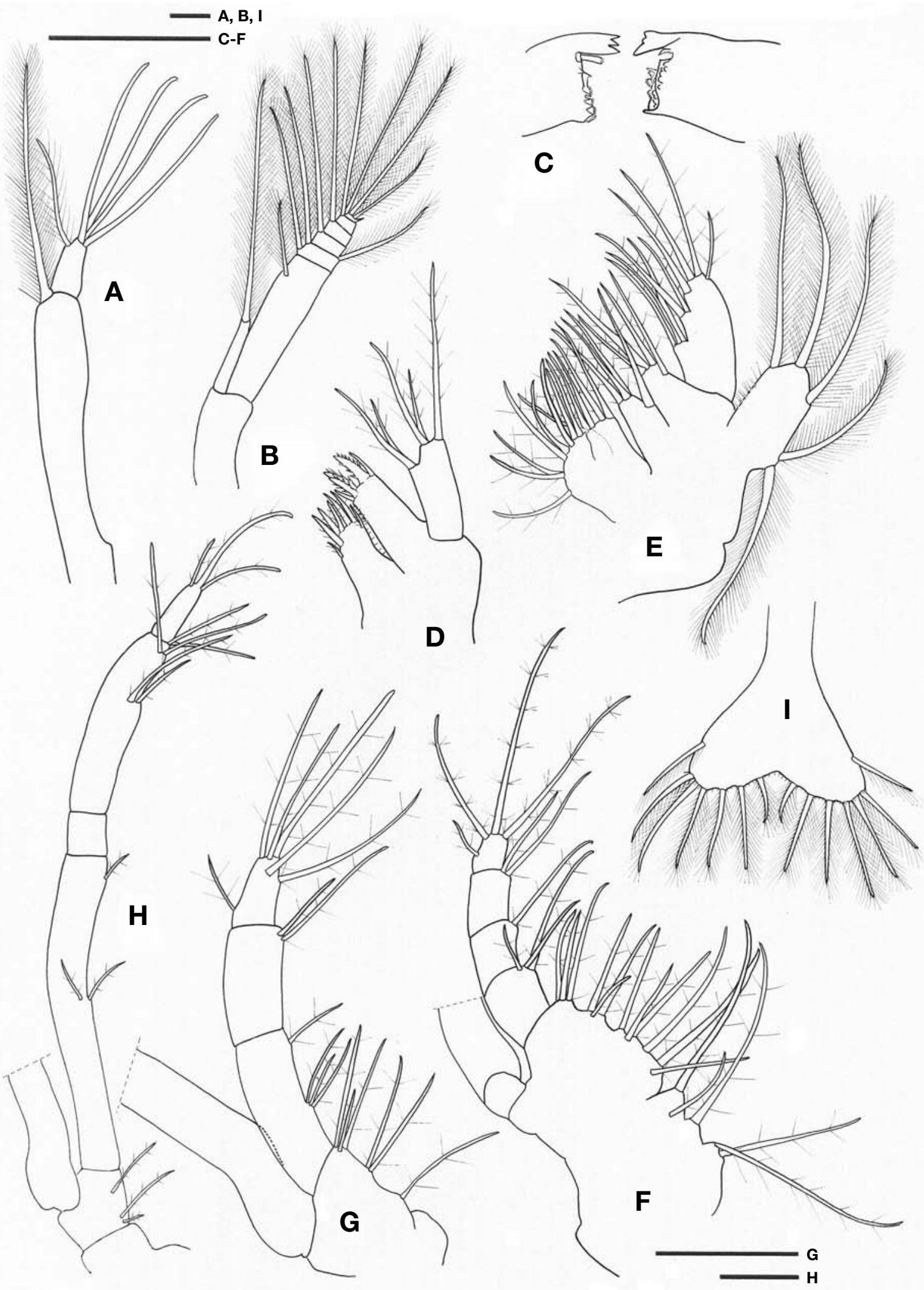

Fig. 2. First zoea of Lysmata vittata (Stimpson, 1860). A, antennule; B, antenna; C, mandibles; D, maxillule; E, maxilla; F, first maxilliped; $\mathrm{G}$, second maxilliped; $\mathrm{H}$, third maxilliped; I, telson. Exopods shown truncated in $\mathrm{F}-\mathrm{H}$. Scale bars $=0.1 \mathrm{~mm}$. 
Antenna (Fig. 2B). Peduncle without distolateral spine; endopod short, 0.36 of exopod, with long plumose seta; scale 6-segmented, with 5 terminal segments, 10 plumose setae, and distolateral spine.

Mandibles (Fig. 2C). Palps absent; left mandible with lacinia mobilis (= movable spine) between molar and incisor processes; right mandible with tooth in that angle.

Maxillule(Fig. 2D). Coxal endite with 7 plumodenticulate setae; basal endite with 5 cuspidate setae; endopod segmented, with 5 ( 2 subterminal +3 terminal) plumodenticulate setae.

Maxilla (Fig. 2E). Coxal endite bilobed, with 9+4 plumodenticulate setae; basal endite bilobed, with $4+4$ plumodenticulate setae; endopod with 9 plumodenticulate setae, arranged 3,2,1,3; scaphognathite with 5 plumose setae.

First maxilliped (Fig. 2F). Coxa with 5 plumodenticulate setae; basis with 12 plumodenticulate setae; endopod 4-segmented, with 3,1,2,3+1 plumodenticulate setae; exopod with 4 ( 1 subterminal+3 terminal) natatory setae (not shown).

Second maxilliped (Fig. 2G). Coxa unarmed; basis with 6 plumodenticulate setae, arranged 1,2,3; endopod 3-segmented, with 4 ( 3 subterminal +1 terminal $), 2,5+1$ plumodenticulate setae; exopod 4 -segmented, with $1+1,1+1,1+1,3$ natatory setae (not shown).

Third maxilliped (Fig. 2H). Coxa unarmed; basis with 3 plumodenticulate setae; endopod slightly longer than exopod, 4-segmented, with 3 (2 subterminal+1 terminal),0,6 (2 subterminal +4 terminal), 3 plumodenticulate setae; exopod 5segmented, with $1+1,1+1,1+1,1+1,3$ natatory setae (not shown).

Pereopods. First and second pereopods present as biramous rudiments.

Abdomen and pleopods (Fig. 1A, B). Composed of 5 abdominal somites: sixth somite not differentiated; fifth somite with pair of dorsolateral spines. Pleopods absent.

Telson and uropod (Fig. 2I). Telson triangular, with deep posterior indentation; margin with 7 pairs of setae; outermost 2 pairs plumose only on inner side; base of all setae except outermost with row of minute spinules. Uropod absent.

Chromatophores. Red chromatophores interspersed with yellow chromatophores present on peduncle and outer flagellum of antennule; scale of antenna; superolateral margin of each eye; dorsally on carapace; mandibles; endopod and exopod of second maxilliped; basis, endopod, and exopod of third maxilliped; dorsally on first to third abdominal somites; laterally on fifth abdominal somite; and supra-region and each lobe of telson.

Second zoea (Figs. 1C, 3)

Duration. 3-5 days.

Size. CL 0.404 (0.400-0.416) mm.

Carapace (Fig. 1C). Supraorbital and antennal spines pre- sent; eyes stalked, with long peduncle, peduncle without spine.

Antennule (Fig. 3A). Peduncle with 2 plumose setae.

Antenna (Fig. 3B). Scale 5-segmented, with 4 terminal segments.

Mandibles (Fig. 3C). Unchanged.

Maxillule(Fig. 3D). Basal endite with 7 cuspidate setae.

Maxilla (Fig. 3E). Unchanged.

First maxilliped(Fig. 3F). Exopod with 5(1 subterminal+4 terminal) natatory setae; terminal setae disposed symmetrically into 2 pairs (not shown).

Second maxilliped (Fig. 3G). Exopod with $1+1,1+1$, $1+1,4$ natatory setae; terminal setae disposed symmetrically into 2 pairs (not shown).

Third maxilliped (Fig. 3H). Exopod with $1+1,1+1,1+1$, $1+1,4$ natatory setae; terminal setae disposed symmetrically into 2 pairs (not shown).

Pereopods. Unchanged.

Abdomen and pleopods (Fig. 1C). Unchanged.

Telson and uropod (Fig. 3I). Telson: posterior margin with 8 pairs of setae; outermost setae plumose only on inner side. Uropod visible.

Third zoea (Figs. 1D, 4)

Duration. 3-5 days.

Size. CL $0.409(0.320-0.464) \mathrm{mm}$.

Carapace (Fig. 1D). Dorsal spine behind rostrum present.

Antennule (Fig. 4A). Peduncle 2-segmented: proximal segment with proximal plumose seta and 5 terminal plumose setae; distal segment with 7 plumose setae; inner flagellum differentiated, with plumose seta; outer flagellum with 2 aesthetascs and plumose seta.

Antenna (Fig. 4B). Endopod short and spine-like; scale 3segmented, with 2 terminal segments, 11 plumose setae, and distolateral spine.

Mandibles (Fig. 4C). Left mandible with lacinia mobilis and tooth between incisor and molar processes; right mandible with 2 teeth in that angle.

Maxillule (Fig. 4D). Unchanged.

Maxilla (Fig. 4E). Unchanged.

First maxilliped (Fig. 4F). Unchanged.

Second maxilliped (Fig. 4G). Unchanged.

Third maxilliped (Fig. 4H). Endopod with 3 (2 subterminal +1 terminal),0,5 (2 subterminal +3 terminal $)+1,3$ setae.

Pereopods. First pereopod (Fig. 4I): basis with plumose seta; endopod 4-segmented, with 4 (2 subterminal+2 terminal), $0+1,3+1,3$ plumose setae; exopod 4-segmented, with $1+1,1+1,1+1,4$ natatory setae (not shown). Second pereopod longer than previous stage. Fifth pereopod present as uniramous rudiment. Other pereopods absent.

Abdomen and pleopods (Fig. 1D). Sixth somite now dif- 


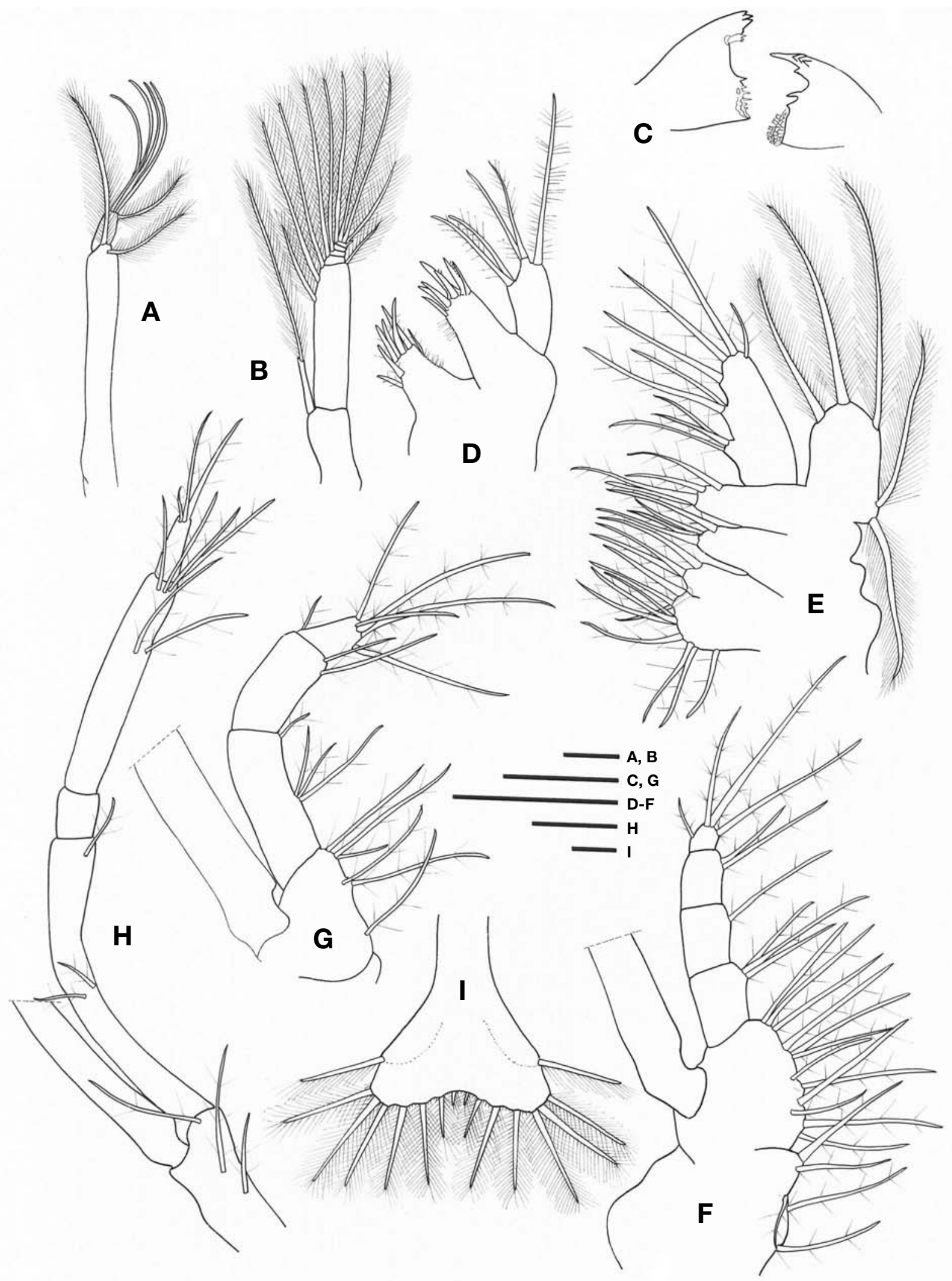

Fig. 3. Second zoea of Lysmata vittata (Stimpson, 1860). A, antennule; B, antenna; C, mandibles; D, maxillule; E, maxilla; F, first maxilliped; $\mathrm{G}$, second maxilliped; $\mathrm{H}$, third maxilliped; $\mathrm{I}$, telson. Exopods shown truncated in $\mathrm{F}-\mathrm{H}$. Scale bars $=0.1 \mathrm{~mm}$. 


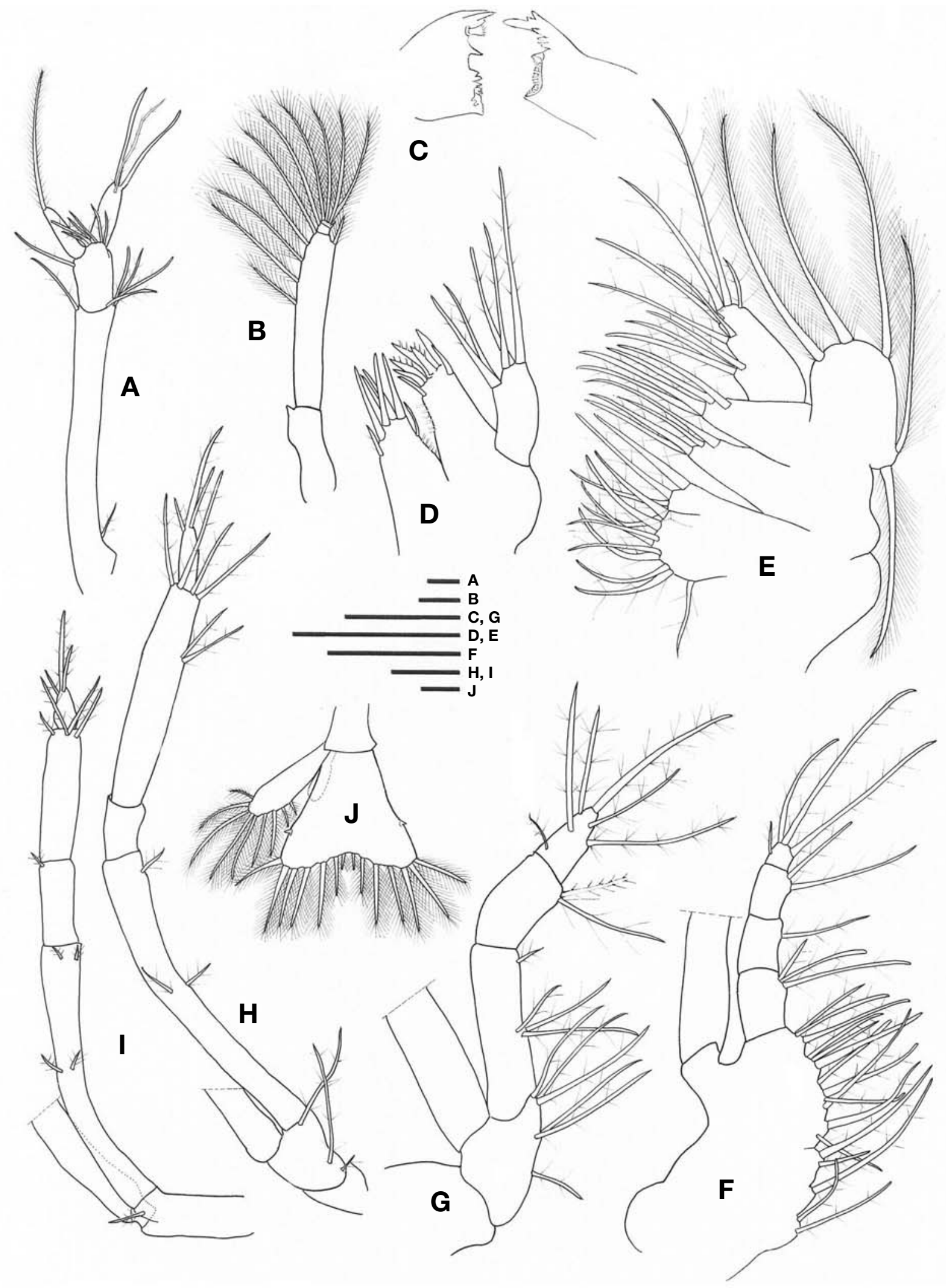

Fig. 4. Third zoea of Lysmata vittata (Stimpson, 1860). A, antennule; $B$, antenna; C, mandibles; $D$, maxillule; $E$, maxilla; $F$, first maxilliped; $\mathrm{G}$, second maxilliped; $\mathrm{H}$, third maxilliped; $\mathrm{I}$, first pereopod; J, telson. Exopods shown truncated in F-I. Scale bars = $0.1 \mathrm{~mm}$. 
ferentiated from telson; posterolateral margin acute. Pleopods unchanged.

Telson and uropod (Fig. 4J). Telson with 7 pairs of posterior setae; lateral margin with pair of spines. Uropod biramous: endopod bud-like; exopod with 9 plumose setae.

Fourth zoea (Figs. 1E, 5)

Duration. 3-5 days.

Size. CL $0.440(0.424-0.466) \mathrm{mm}$.

Carapace (Fig. 1E). Unchanged.

Antennule (Fig. 5A). Peduncle with 1 proximal, 3 subterminal, and 4 terminal plumose setae on proximal segment.

Antenna (Fig. 5B). Scale segmented, with 14 plumose setae and distolateral spine.

Mandibles (Fig. 5C). Left mandible with lacinia mobilis and 2 teeth between incisor and molar processes.

Maxillule (Fig. 5D). Unchanged.

Maxilla(Fig. 5E). Scaphognathite with 8 plumose setae.

First maxilliped (Fig. 5F). Unchanged.

Second maxilliped (Fig. 5G). Unchanged.

Third maxilliped (Fig. 5H). Endopod with 4 (2 subterminal +2 terminal), 1,8,3 plumose setae.

Pereopods. First pereopod (Fig. 5I): endopod with 3 (2 subterminal +1 terminal $)+1,0+1,5(2$ subterminal +3 terminal $)+$ 1,3 plumose setae; exopod 5 -segmented, with $1+1,1+1$, $1+1,1+1,4$ natatory setae (not shown). Second and fifth pereopods longer than previous stage. Third and fourth pereopods present as uniramous rudiments.

Abdomen and pleopods (Fig. 1E). Unchanged.

Telson and uropod(Fig. 5J). Telson unchanged. Uropod: protopod developed; endopod with 6 plumose setae; exopod with 11 plumose setae and outer spine.

Fifth zoea (Fig. 6)

Duration. 3-5 days.

Size. CL $0.464(0.432-0.520) \mathrm{mm}$.

Carapace. Anteroventral margin with pterygostomian spine and 2 denticles.

Antennule (Fig. 6A). Peduncle with 2 proximal, 4 subterminal and 4 terminal plumose setae on proximal segment; outer flagellum with 3 aesthetascs ( 2 subterminal +1 terminal) and plumose seta.

Antenna(Fig. 6B). Peduncle 2-segmented.

Mandibles (Fig. 6C). Unchanged.

Maxillule(Fig. 6D). Coxal endite with 8 plumodenticulate setae.

Maxilla (Fig. 6E). Unchanged.

First maxilliped (Fig. 6F). Unchanged.

Second maxilliped (Fig. 6G). Unchanged.

Third maxilliped (Fig. 6H). Endopod with 4(2 subterminal
+2 terminal), $0+1,8,3$ plumodenticulate setae.

Pereopods. First (Fig. 6I) to fourth pereopods unchanged. Fifth pereopod (Fig. 6J) uniramous, paddle-like, 2-segmented: proximal segment with distolateral margin acute; distal segment with plumose seta.

Abdomen and pleopods. Fifth abdominal somite without dorsolateral spines. Pleopods developed as uniramous buds.

Telson and uropod (Fig. 6K). Telson unchanged. Uropod: endopod with 8 plumose setae; exopod with 14 plumose setae and outer spine.

Sixth zoea (Fig. 7)

Duration. 3-5 days.

Size. CL 0.611 (0.600-0.624) mm.

Carapace. Anteroventral margin with pterygostomian spine and denticle.

Antennule (Fig. 7A). Peduncle with 4 proximal, 5 subterminal and 4 terminal setae; outer flagellum with 3 aesthetascs and 2 plumose setae.

Antenna(Fig. 7B). Scale with 15 plumose setae and distolateral spine.

Mandibles (Fig. 7C). Left mandible with 2 laciniae mobiles and 2 teeth between incisor and molar processes.

Maxillule (Fig. 7D). Unchanged.

Maxilla(Fig. 7E). Coxal endite with $11+4$ plumodenticulate setae.

First maxilliped (Fig. 7F). Epipod developed.

Second maxilliped (Fig. 7G). Unchanged.

Third maxilliped (Fig. 7H). Exopod 6-segmented, with $1+1,1+1,1+1,1+1,1+1,4$ natatory setae (not shown).

Pereopods. First pereopod (Fig. 7I) unchanged. Second pereopod (Fig. 7J) biramous; coxa unarmed; basis with plumose seta; endopod 4-segmented, with 3 (2 median+1 subterminal) $+1,0+1,3+1,3$ plumose setae; exopod 4-segmented, with $1+1,1+1,1+1,4$ natatory plumose setae (not shown). Third and fourth pereopods unchanged. Fifth pereopod (Fig. $7 \mathrm{~K}$ ) uniramous; coxa and basis unarmed; endopod paddlelike, 5-segmented, with 0,2+1,0+1,6,2 plumose setae.

Abdomen and pleopods. Unchanged.

Telson and uropod (Fig. 7L). Telson unchanged. Uropod: endopod with 10 plumose setae; exopod with 15 plumose setae and outer spine.

Seventh zoea (Fig. 8)

Duration. 3-5 days.

Size. CL $0.650(0.620-0.684) \mathrm{mm}$.

Carapace. Unchanged.

Antennule (Fig. 8A). Peduncle with 8 proximal, 12 subterminal and 4 terminal setae on proximal segment; inner flagellum slightly longer than outer flagellum. 


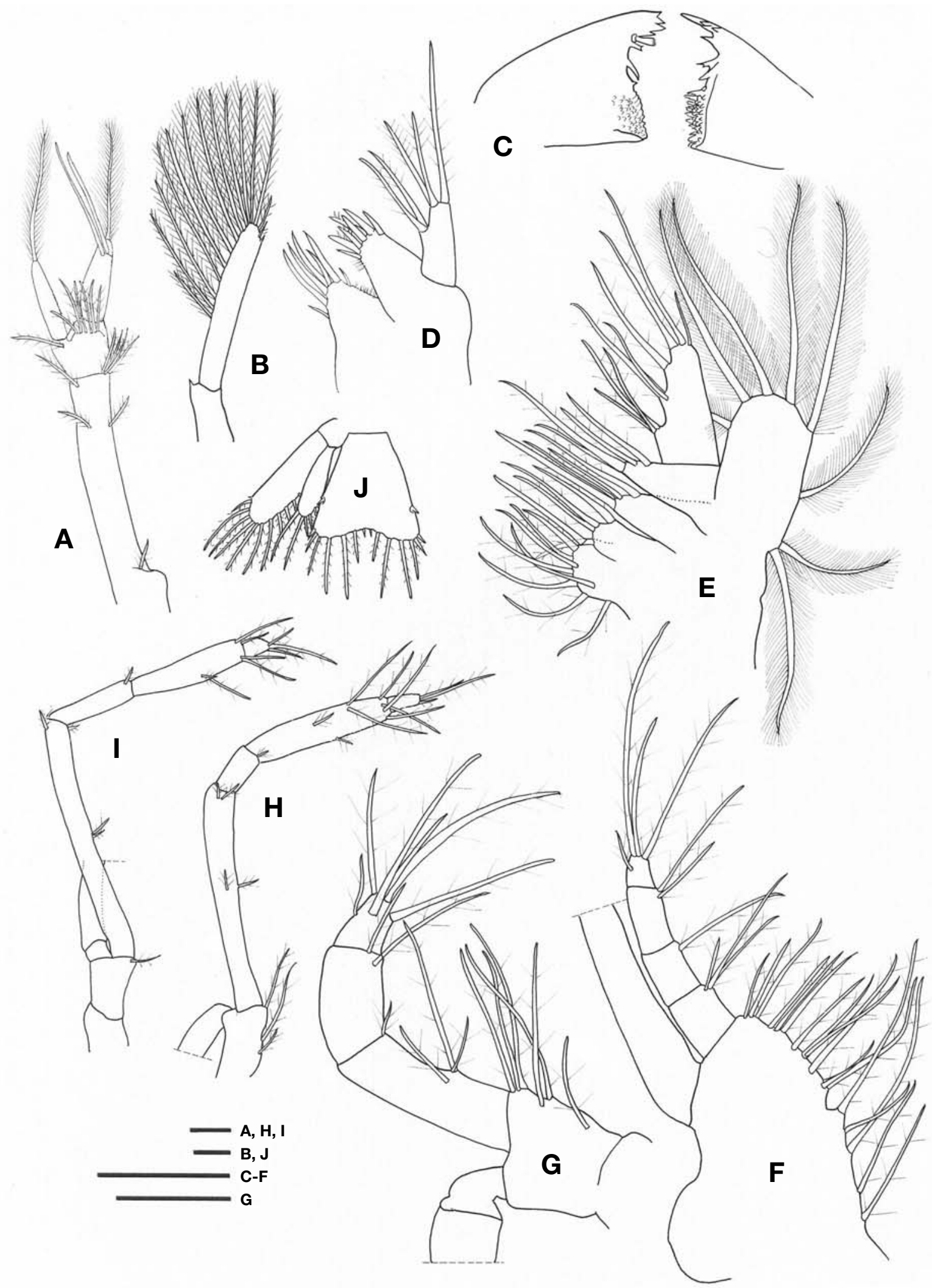

Fig. 5. Fourth zoea of Lysmata vittata (Stimpson, 1860). A, antennule; B, antenna; C, mandibles; $D$, maxillule; $E$, maxilla; $F$, first maxilliped; $\mathrm{G}$, second maxilliped; $\mathrm{H}$, third maxilliped; $\mathrm{I}$, first pereopod; J, telson. Exopods shown truncated in F-I. Scale bars $=0.1 \mathrm{~mm}$. 


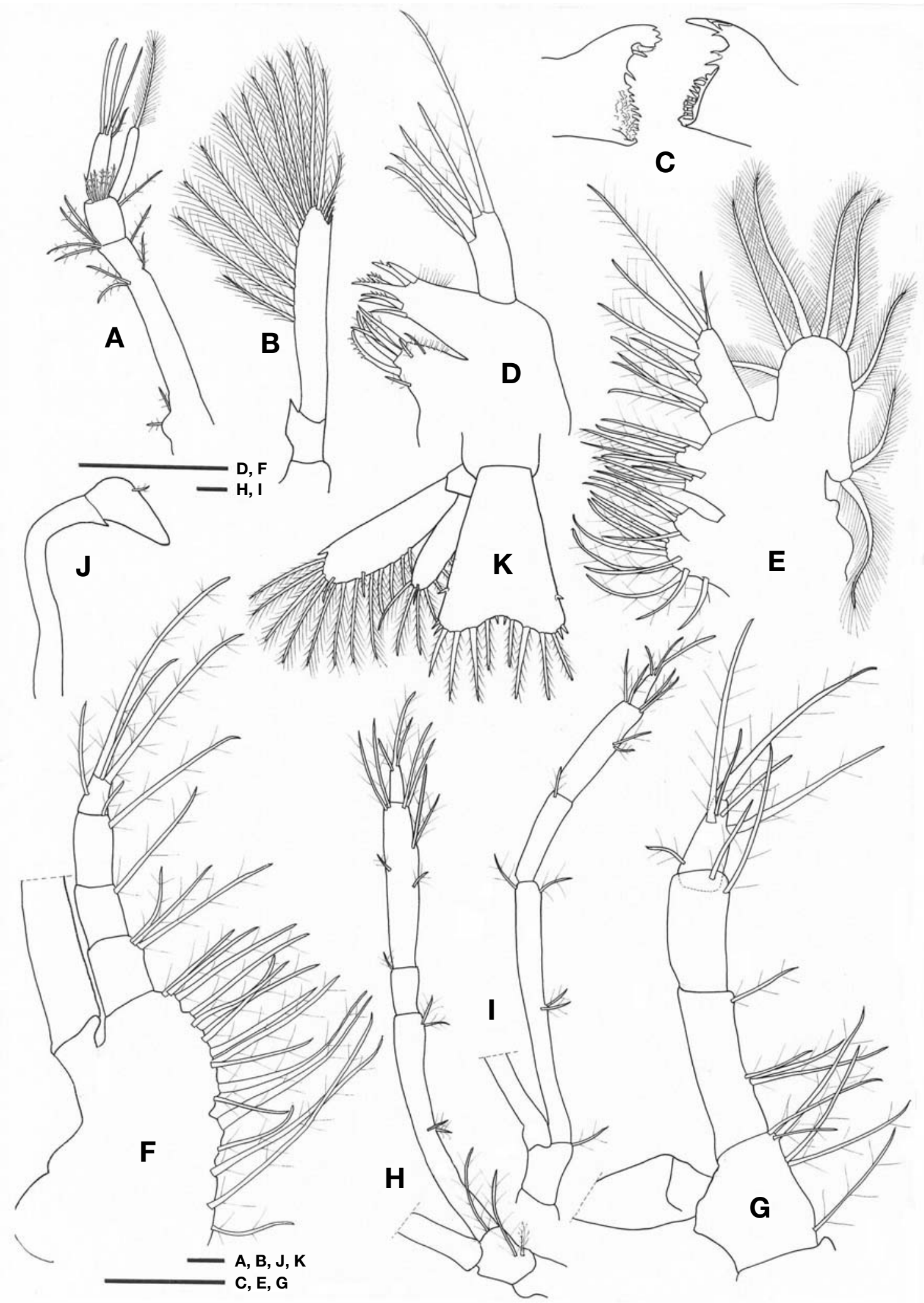

Fig. 6. Fifth zoea of Lysmata vittata (Stimpson, 1860). A, antennule; B, antenna; C, mandibles; D, maxillule; E, maxilla; F, first maxilliped; $\mathrm{G}$, second maxilliped; $\mathrm{H}$, third maxilliped; $\mathrm{I}$, first pereopod; J, fifth pereopod; $\mathrm{K}$, telson. Exopods shown truncated in $\mathrm{F}$-I. Scale bars $=0.1 \mathrm{~mm}$. 
Hoi Jeong Yang and Chang Hyun Kim



Fig. 7. Sixth zoea of Lysmata vittata (Stimpson, 1860). A, antennule; B, antenna; C, mandibles; D, maxillule; E, maxilla; F, first maxilliped; $G$, second maxilliped; $H$, third maxilliped; $I$, first pereopod; $J$, second pereopod; $K$, fifth pereopod; $L$, telson. Exopods shown truncated in F-J. Scale bars $=0.1 \mathrm{~mm}$. 


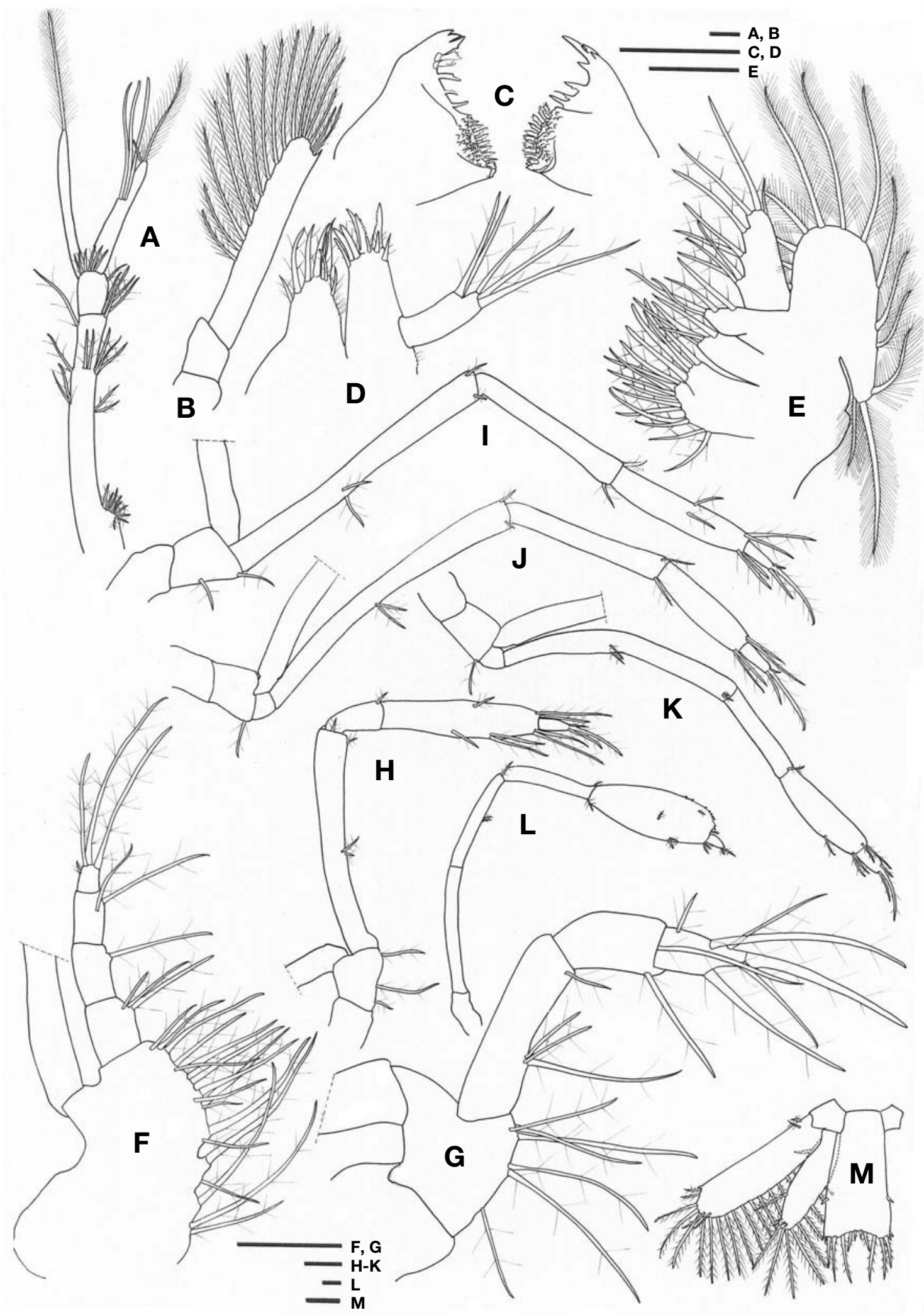

Fig. 8. Seventh zoea of Lysmata vittata (Stimpson, 1860). A, antennule; $B$, antenna; C, mandibles; $D$, maxillule; $E$, maxilla; $F$, first maxilliped; G, second maxilliped; H, third maxilliped; I, first pereopod; J, second pereopod; K, third pereopod; L, fifth pereopod; M, telson. Exopods shown truncated in F-K. Scale bars $=0.1 \mathrm{~mm}$. 
Antenna (Fig. 8B). Scale with 16 plumose setae and distolateral spine.

Mandibles (Fig. 8C). Left mandible with 2 laciniae mobiles and 3 teeth between incisor and molar processes; right mandible with 3 teeth in that angle.

Maxillule (Fig. 8D). Basal endite with 8 cuspidate setae.

Maxilla(Fig. 8E). Scaphognathite with 13 plumose setae.

First maxilliped (Fig. 8F). Basis with 13 plumodenticulate setae.

Second maxilliped (Fig. 8G). Exopod 6-segmented, with $1+1,1+1,1+1,1+1,1+1,4$ natatory setae (not shown).

Third maxilliped (Fig. 8H). Unchanged.

Pereopods. First pereopod (Fig. 8I): basis with 2 plumose setae; endopod with 3 ( 2 subterminal +1 terminal $)+1,1+1$, 4 ( 2 subterminal +2 terminal $)+2,3$ plumose setae; exopod 6 segmented, with $1+1,1+1,1+1,1+1,1+1,4$ natatory setae. Second pereopod (Fig. 8J): endopod 5-segmented, with 0,3 (2 subterminal +1 terminal $)+1,1+1,2+2,3$ plumose setae; exopod 5-segmented, with $1+1,1+1,1+1,1+1,4$ natatory setae (not shown). Third pereopod (Fig. 8K) biramous; coxa unarmed; basis with plumose seta; endopod 5-segmented, with 0,4 ( 2 subterminal +2 terminal), 1,3 (1 subterminal +2 terminal) +2 , 3 plumose setae; exopod 4-segmented, with $1+1,1+1,1+1,4$ natatory setae (not shown). Fourth pereopod unchanged. Fifth pereopod (Fig. 8L): endopod with $0,2+$ $1,1+1,7,2$ plumose setae; propodus serrated, with 9 denticles on outer margin.

Abdomen and pleopods. Abdomen unchanged. Pleopods present as biramous rudiments.

Telson and uropod (Fig. 8M). Telson: posterior width slightly greater than anterior width. Uropod: endopod with 15 plumose setae; exopod with 22 plumose setae and outer spine.

Eighth zoea (Figs. 9, 10)

Duration. 3-5 days.

Size. CL 0.714 (0.680-0.725) mm.

Carapace. Unchanged.

Antennule (Fig. 9A). Peduncle with 9 proximal, 13 subterminal and 4 terminal plumose setae on proximal segment; inner flagellum with 3 plumose setae; outer flagellum 2segmented: proximal segment with 3 aesthetascs; distal segment with 4 aesthetascs and 3 terminal plumose setae.

Antenna (Fig. 9B). Endopod corn-shaped, with terminal plumose seta; scale with 18-23 plumose setae and distolateral spine.

Mandibles (Fig. 9C). Left mandible with 3 laciniae mobiles and 4 teeth between incisor and molar processes; right mandible with 4 teeth in that angle.

Maxillule (Fig. 9D). Unchanged.

Maxilla (Fig. 9E). Basal endite with $5+5$ plumodenticulate setae; scaphognathite with 17 plumose setae.
First maxilliped (Fig. 9F). Unchanged.

Second maxilliped (Fig. 9G). Unchanged.

Third maxilliped (Fig. 10A). Endopod with 4 (2 subterminal +2 terminal), $0+1,4+10,3$ plumodenticulate setae.

Pereopods. First to third pereopods (Fig. 10B-D): endopods 5-segmented. Fourth pereopod (Fig. 10E) biramous; coxa unarmed; basis with plumose seta; endopod 4-segmented, with 3 ( 3 subterminal +1 terminal) $+1,0+1,2+2,3$ plumose setae; exopod 4-segmented, with $1+1,1+1,1+1,4$ natatory setae (not shown). Fifth pereopod (Fig. 10F): endopod bearing propodus serrated on inner and outer margins.

Abdomen and pleopods. Abdomen unchanged. Pleopods longer than in previous stage.

Telson and uropod (Fig. 10G). Telson, posterior width slightly narrower than anterior width; posterior margin with 6 pairs of setae; lateral margin with 2 pairs of spines. Uropod: endopod with 26 plumose setae; exopod with 30 plumose setae and outer spine.

Ninth zoea (Figs. 11, 12)

Duration. 3-5 days.

Size. CL 0.803 (0.784-0.832) mm.

Carapace. Ventral margin without anterior denticles.

Antennule (Fig. 11A). Peduncle with 10 proximal, 13 subterminal and 4 terminal plumose setae on proximal segment; inner flagellum 2-segmented, with 1, 3 plumose setae; outer flagellum 7-segmented; each segment with sensory hairs; second segment with 4 aesthetascs (1 subterminal+3 terminal); third segment with 3 subterminal aesthetascs.

Antenna (Fig. 11B). Endopod elongated; scale with 22-25 plumose setae and distolateral spine.

Mandibles (Fig. 11C). Unchanged.

Maxillule (Fig. 11D). Coxal endite with 10 plumodenticulate setae; basal endite with 10 cuspidate setae.

Maxilla(Fig. 11E). Basal endite with $6+5$ plumodenticulate setae; scaphognathite with 23-26 plumose setae.

First maxilliped (Fig. 11F). Basis with 14 plumodenticulate setae.

Second maxilliped (Fig. 11G). Unchanged.

Third maxilliped (Fig. 12A). Endopod 5-segmented, with $2,1+1,0+1,11,3$ plumose setae.

Pereopods. First to fourth pereopods (Fig. 12B-E) with exopods. First to fifth pereopods: endopods 5-segmented; dactylus acute. Fifth pereopod (Fig. 12F) without exopod; merus and carpus with distolateral margin acute.

Abdomen and pleopods. Abdomen unchanged. First to fifth pleopods: endopods and exopods with several plumose setae.

Telson and uropod. Telson: posterior width narrower than anterior width. Uropod: endopod with 30-34 plumose setae; exopod with 30-35 plumose setae and outer spine. 


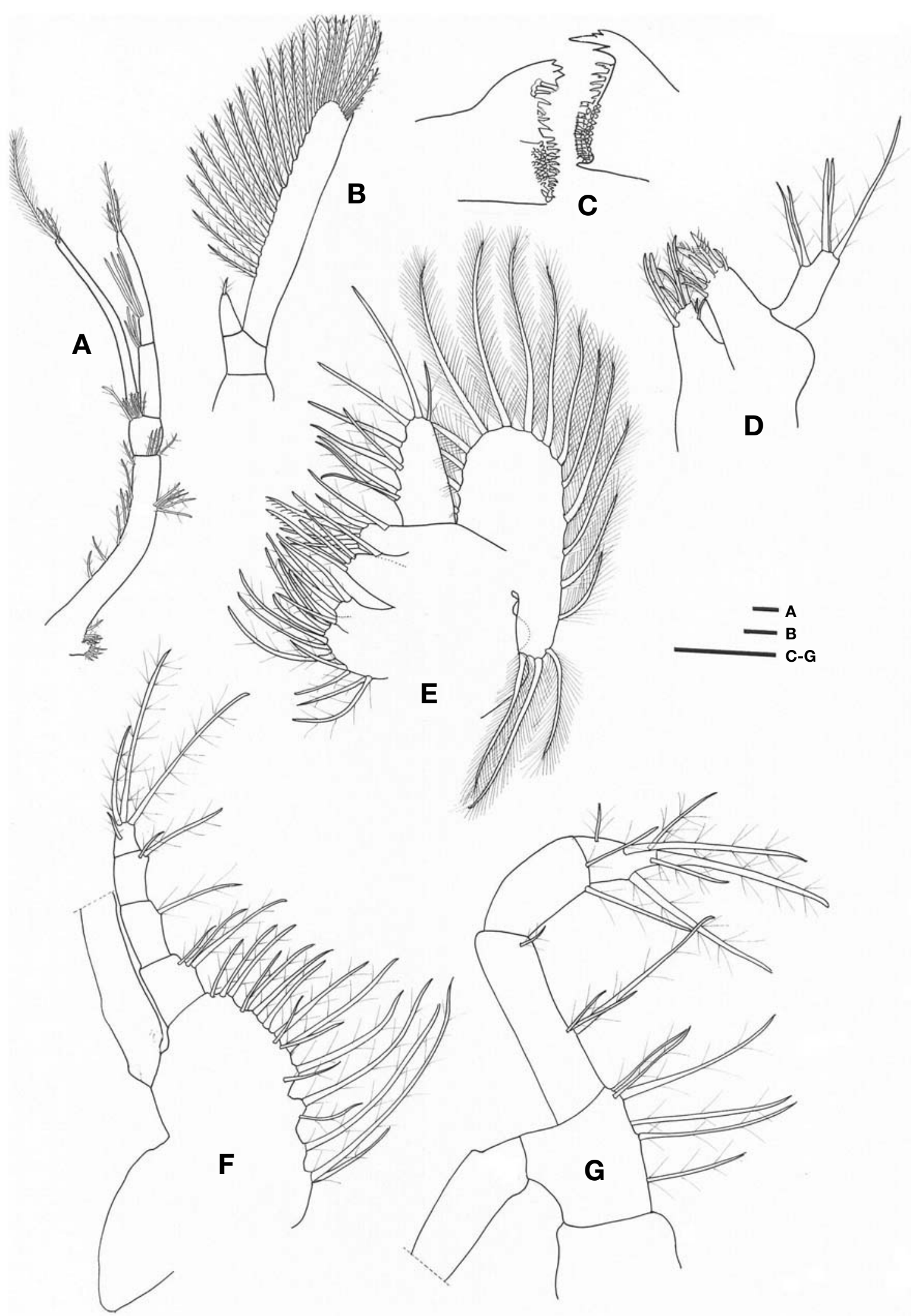

Fig. 9. Eighth zoea of Lysmata vittata (Stimpson, 1860). A, antennule; B, antenna; C, mandibles; D, maxillule; E, maxilla; F, first maxilliped; G, second maxilliped. Exopods shown truncated in F-G. Scale bars $=0.1 \mathrm{~mm}$. 


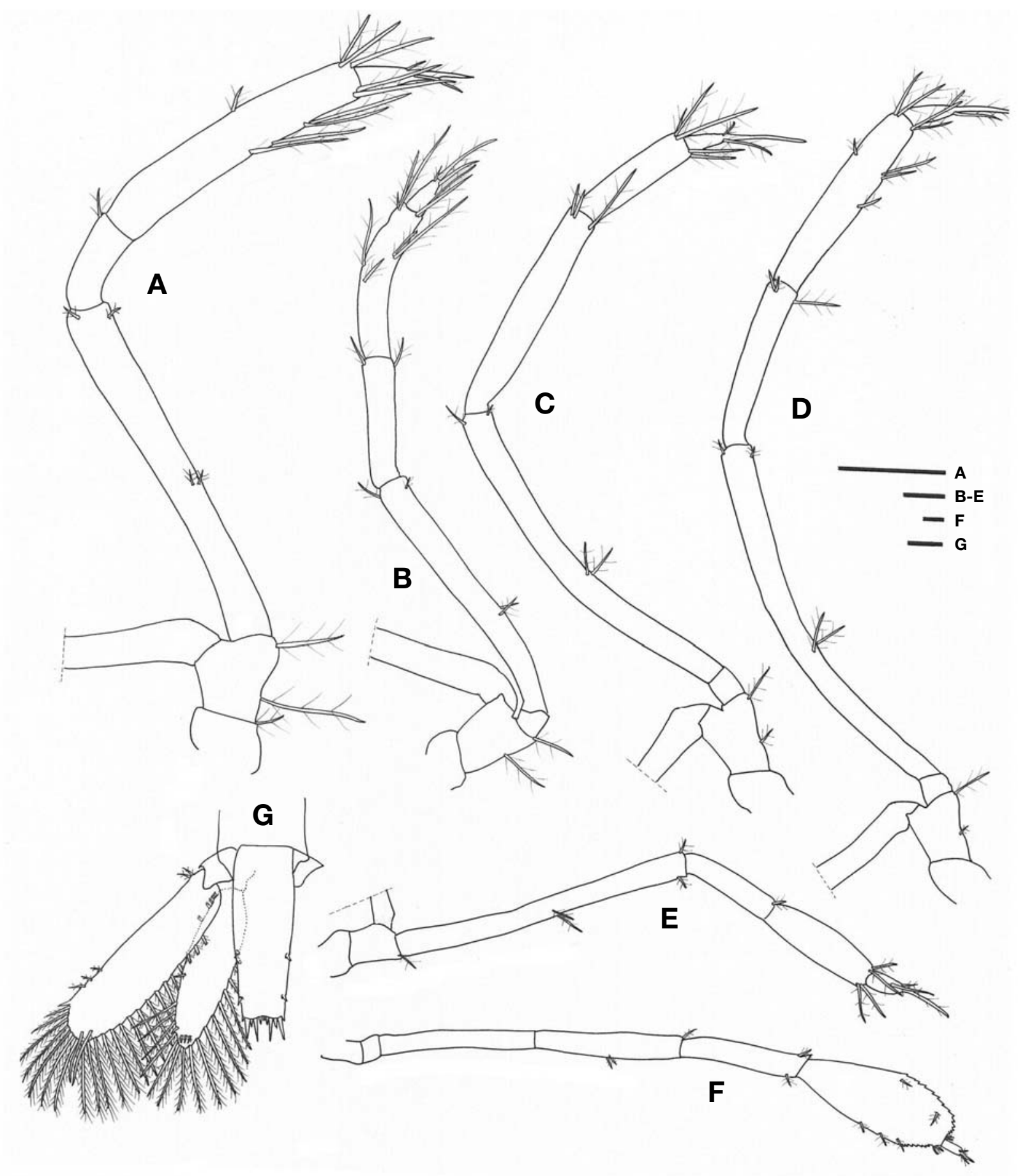

Fig. 10. Eighth zoea of Lysmata vittata (Stimpson, 1860). A, third maxilliped; B, first pereopod; C, second pereopod; D, third pereopod; $E$, fourth pereopod; $F$, fifth pereopod; $G$, telson. Exopods shown truncated in A-E. Scale bars $=0.1 \mathrm{~mm}$.

\section{DISCUSSION}

Some morphological characteristics of the first zoeas of Lysmata vittata described in the present study, particularly on the length of the rostrum and the ornamentation of the carapace, differ from those of the earlier descriptions. Kuriyan (1951) who dealt with the first zoeas hatched from ovigerous females collected from Krusadai, Indian waters, 


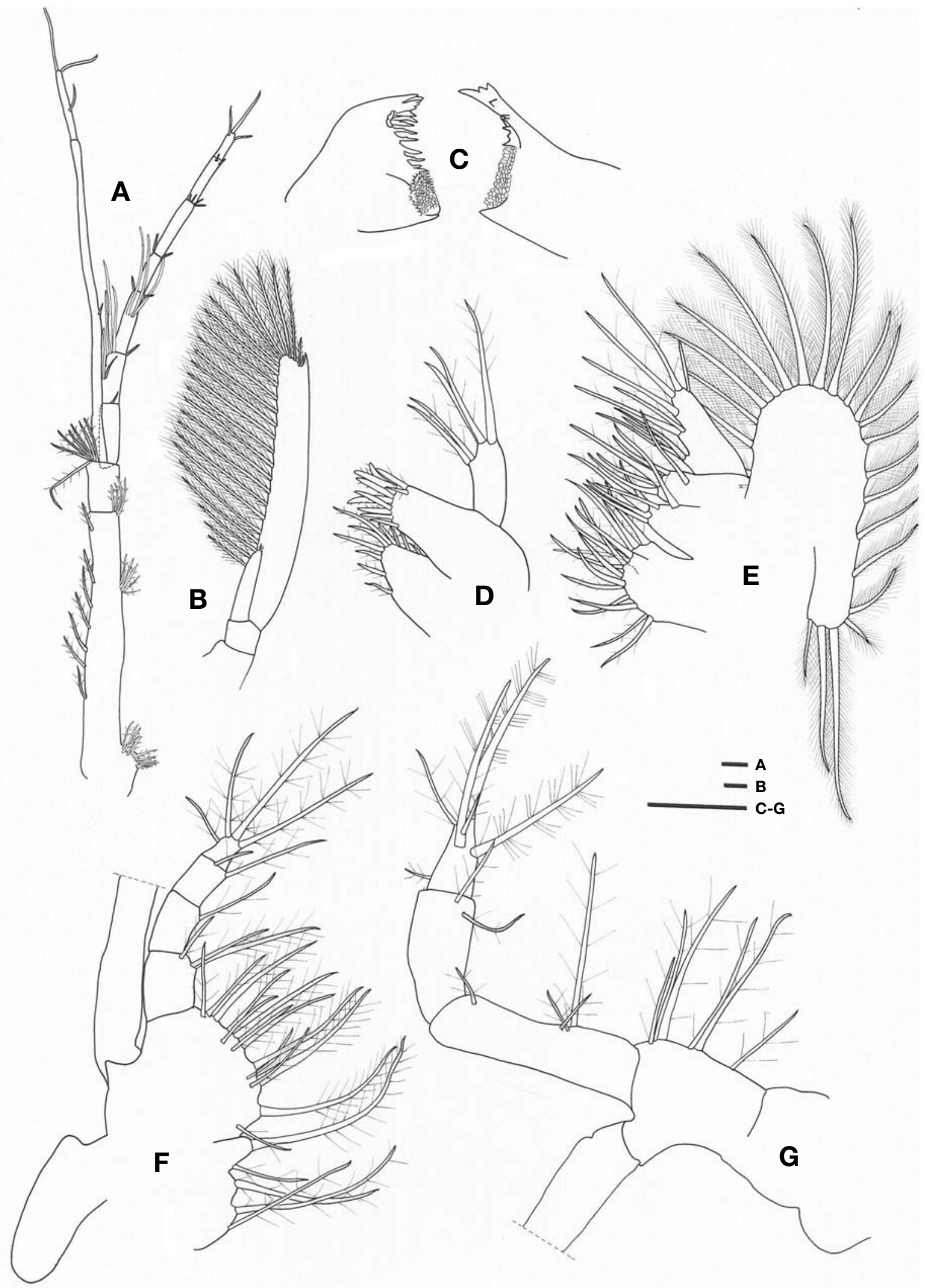

Fig. 11. Ninth zoea of Lysmata vittata (Stimpson, 1860). A, antennule; $B$, antenna; C, mandibles; $D$, maxillule; $E$, maxilla; $F$, first maxilliped; G, second maxilliped. Exopods shown truncated in F-G. Scale bars $=0.1 \mathrm{~mm}$. 


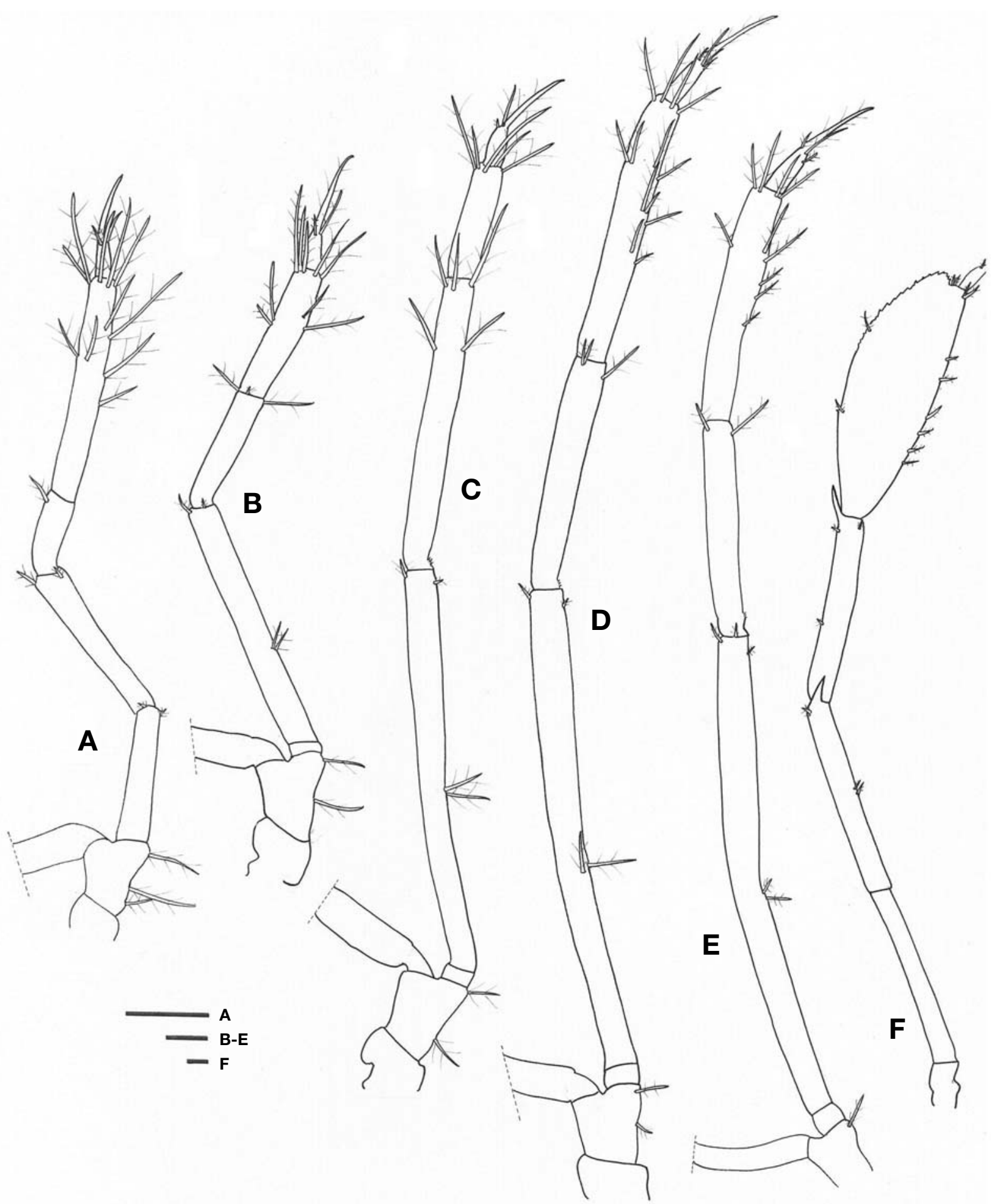

Fig. 12. Ninth zoea of Lysmata vittata (Stimpson, 1860). A, third maxilliped; B, first pereopod; C, second pereopod; D, third pereopod; E, fourth pereopod; $F$, fifth pereopod. Exopods shown truncated in A-E. Scale bars $=0.1 \mathrm{~mm}$.

reported that the rostrum extended beyond the end of the peduncle of antennule. The previous author also noted that there were no anteroventral denticles and pterygostomian spine on the carapace. Pillai (1966) also working with Indian specimens of the larvae obtained from ovigerous females collected off Cannanore, observed that the rostrum reached 
Table 1. Characteristics of hippolytid first zoeas. * = data from the eighth zoeal stage; $* *=$ data from the ninth zoeal stage

\begin{tabular}{lcl}
\hline \multicolumn{1}{c}{ Species } & Maxilliped II basis setation & \multicolumn{1}{c}{ References } \\
\hline Latreutes laminiIrostris Ortmann, 1890 & $1,2,2,3(8)$ & Yang and Park, 2004 \\
Latreutes anoplonyx Kemp, 1914 & $1,2,2,3(8)$ & Yang, 2005 \\
Chorismus tuberculatus Bate, 1888 & $1,2,3,3(9)$ & Thatje and Bacardit, 2000 \\
Nauticaris magellanica (A. Milne-Edwards, 1891) & $1,2,3,3(9)$ & Wehrtmann and Albornoz, 1998 \\
Tozeuma carolinense Kingsley, 1878 & $1,2,3,3(9) *$ & Ewald, 1969 \\
Heptacarpus futilirostris (Bate, 1888) & $1,2,3,3(9)$ & Yang and Kim, 2005 \\
Heptacarpus rectirostris (Stimpson, 1860) & $1,2,3,3(9)$ & Yang and Ko, 2002 \\
Thor amboinensis (De Man, 1888) & $1,2,3,3(9)$ & Yang and Okuno, 2004 \\
Eualus sinensis (Yu, 1931) & $1,2,3,3(9)$ & Yang et al., 2001 \\
Eualus leptognathus (Stimpson, 1860) & $1,2,3,3(9)$ & Yang and Kim, 2006b \\
Exhippolysmata oplophoroides (Holthuis, 1948) & $1,2,3(6)$ & Personal observation \\
Lysmata vittata (Stimpson, 1860) & $1,2,3(6)$ & Present study \\
Lysmata anchisteus Chace, 1972 & $1,2,3(6) * *$ & Knowlton and Alavi, 1995 \\
\hline
\end{tabular}

to the end of the peduncle of antennule in dorsal view. In present specimens, the rostrum reached to the half length of the peduncle of antennule in dorsal view and the carapace had three anteroventral denticles and pterygostomian spine. The difference in rostrum could be due to intraspecific variation, similar to that found in other Caridean first zoeas of Periclimenes brevicarpalis (Schenkel, 1902) between Indian specimens described by Nayer (1947) and Japanese specimens by Nagai and Shokita (2003). However, difference of the ornamentation of the carapace is of doubt. In his work of the summary of the larval characters of hippolytid genera, Gurney (1937) regarded that denticulated anteroventral margin of the carapace is a valid characteristic of the genus Lysmata. Moreover, according to Pillai (1966), three anteroventral denticles and pterygostomian spine were present on the carapace in Cannanore specimens. Furthermore, Knowlton and Alabi (1995) and Calado et al. (2004) reported that the anteroventral margin of the carapace in the larvae of $L$. anchisteus and L. seticaudata is also denticulated. The denticulation of the anteroventral margin of the carapace disappeared from the seventh zoeas of $L$. seticaudata described by Calado et al. (2004) and the ninth zoeas of L. anchisteus described by Knowlton and Alabi (1995). This disappearance was also found from the seventh zoeas of Korean specimens of L. vittata. Based on Gurney (1937)'s viewpoint and the description given by Pillai (1966), as well as the known larval characteristics of $L$. anchisteus and L. seticaudata, the discrepancy for the ornamentation of the carapace in description likely resulted from Kuriyan's inaccurate observation.

There are two other larval descriptions of Lysmata: $L$. anchisteus described by Knowlton and Alavi (1995) and $L$. seticaudata described by Calado et al. (2004). The fifth abdominal somite in the first zoeas of L. anchisteus is devoid of a pair of dorsolateral spines, while, in those of L. vittata and L. seticaudata, it is armed with paired dorsolateral spines. Six anteroventral denticles and pterygostomian spine are present on the carapace in the first zoeas of L. seticaudata, whereas, in the first zoeas of $L$. vittata, three anteroventral denticles and pterygostomian spine are present on the carapace. The ornamentation of the carapace and the fifth abdominal somite, therefore, readily distinguishes the first zoeas of $L$. vittata from those of $L$. anchisteus and L. seticaudata.

The larvae of Lysmata can be characterized by: 1) the rostrum simple, slender, pointed in the first zoeas; 2) anterior dorsomedian papilla present on the carapace (confirmation needed); 3) the pterygostomian spine present in the first zoeas; 4) the supraorbital and antennal spines present from the second zoeas; 5 ) the eyestalk being long from the second zoeas; 6) the fifth abdominal somite with or without dorsolateral spine in the first zoeas; 7) the antennule bearing the scale with terminal segments in the first zoeas; 8) the maxillule without outer seta, segmented endopod with three terminal setae; 9) the maxilla with 2-lobed coxal endite, the endopod with nine setae arranged 3,2,1,3, the scaphognathite with five marginal plumose setae in the first zoeas; 10) the first maxilliped with 4-segmented endopod in the first zoeas, the exopod with three terminal natatory setae in the first zoeas; 11) the second maxilliped bearing basis with six setae arranged $1,2,3$, the exopod with three terminal natatory setae in the first zoeas; 12) the third maxilliped with endopod longer than exopod, the exopod with three terminal natatory setae in the first zoeas; 13) the first to fourth pereopods with exopods; and 14) the fifth pereopod paddle-like, the propodus expanded.

Of the known larvae of the nine different genera of the Hippolytidae (Chorismus, Eualus, Exhippolysmata, Heptacarpus, Latreutes, Lysmata, Nauticaris, Thor, and Tozeuma), the setation of 1, 2,3(6) on the basis of the second maxilliped is characteristic for the larvae of Lysmata and Exhippolysmata indicating that both genera are closely related to each other (Table 1). 


\section{REFERENCES}

Bourdillon-Casanova, L., 1960. Le méroplancton du golfe de Marseille: les larves du Crustacés Décapodes. Recl. Trav. Stat. Mar. Endoume, 30: 1-286.

Calado, R., C. Bartilotti, L. Narciso and A.D. Santos, 2004. Redescription of the larval stages of Lysmata seticaudata (Risso, 1816) (Crustacea, Decapoda, Hippolytidae) reared in the laboratory. J. Plankt. Res., 26: 737-752.

Caroli, E., 1918. Miersia clavigera Chun, stadio misidiforme di Lysmata seticaudata. Publ. Staz. Zool. Napoli, 2: 1-177.

Chace, F.A., Jr., 1997. The caridean shrimps (Crustacea: Decapoda) of the 'Albatross' Philippine Expedition, 1907-1910, Part 7: Families Atyidae, Eugonatonotidae, Rhynchocinetidae, Bathypalaemonellidae, Processidae, and Hippolytidae. Smithson. Contrib. Zool., 587: 1-106.

Debelius, H., 2001. Crustacea Guide of the World, UW-ArchivIkan, Frankfurt, Germany, pp. 1-321.

Ewald, J.J., 1969. Observations on the biology of Tozeuma carolinense (Decapoda, Hippolytidae) from Florida, with special reference to larval development. Bull. Mar. Sci., 19: 510-549.

Gurney, R., 1937. Larvae of decapod Crustacea. Part IV: Hippolytidae. Disc. Rep., 14: 351-404.

Hayashi, K.I., 1994. Prawns, shrimps and lobsters from Japan (78). Family Hippolytidae-genera Lysmatella and Lysmata. Aquabiology, 16: 270-274. (in Japanese)

Knowlton, R.E. and M.R. Alabi, 1995. The larval morphology of Lysmata anchisteus Chace (Crustacea: Decapoda) compared with other Lysmata spp. Caribbean J. Sci., 31: 289-310.

Kurian, C.V., 1956. Larvae of decapod Crustacea from the Adriatic Sea. Acta Adriatica, 6: 1-108.

Kuriyan, G.K., 1951. A note on the eggs and the first stage larva of Hippolysmata vittata Stimpson. J. Bombay nat. Hist. Soc., 50: 416-417.

Nagai, T. and S. Shokita, 2003. Larval development of a Pontoniine shrimp, Periclimenes brevicarpalis (Crustacea: Decapoda: Palaemonidae) reared in the laboratory. Spec. Div., 8: 237-265.

Nayer, S.G., 1947. The newly hatched larva of Periclimenes (Ancylocaris) brevicarpalis (Shenkel). Proc. Indian Acad. Sci., Sec. B, 26: 168-176.

Pillai, S.V., 1966. Some observations on the early larval stages of Hippolysmata vittata (Stimpson). J. Mar. Biol. Ass. India, 8: 152-158.

Thatje, S. and R. Bacardit, 2000. Larval stages of Chorismus tuberculatus (Decapoda: Caridea: Hippolytidae) from the south-western Atlantic Ocean. J. Mar. Biol. Ass. U.K., 80: 465-471.

Wehrtmann, I.S. and L. Albornoz, 1998. Larval development of Nauticaris magellanica (A. Milne Edwards, 1891)(Decapoda: Caridea: Hippolytidae), reared under laboratory conditions. Bull. Mar. Sci., 62: 45-72.

Yang, H.J., 2005. Larval development of Latreutes anoplonyx (Decapoda: Hippolytidae) reared in the laboratory. J. Crust. Biol., 25: 462-479.

Yang, H.J., 2009. Zoeal stages of fat-handed snapping shrimp Synalpheus tumidomanus (Paulson, 1875) (Decapoda, Caridea, Alpheidae) reared in the laboratory. Korean J. Syst. Zool., 22: 117-120.

Yang, H.J. and C.H. Kim, 2005. Zoeal stages of Heptacarpus futilirostris (Decapoda, Caridea, Hippolytidae) reared in the laboratory. Crustaceana, 78: 543-564.

Yang, H.J. and H.S. Ko, 2002. First zoea of Heptacarpus rectirostris (Decapoda, Caridea, Hippolytidae) hatched in the laboratory, with notes on the larval characters of Heptacarpus. Korean J. Syst. Zool., 18: 191-201.

Yang, H.J., H.S. Ko and C.H. Kim, 2001. The first zoeal stage of Eualus sinensis (Yu, 1931) (Decapoda, Caridea, Hippolytidae), with a key to the known first hippolytid zoeae from Korea and adjacent waters. Crustaceana, 74: 1-9.

Yang, H.J. and J. Okuno, 2004. First larvae of Lebbeus comanthi and Thor amboinensis (Decapoda: Hippolytidae) hatched in the laboratory. Korean J. Biol. Sci., 8: 19-25.

Yang, H.J. and J.B. Park, 2004. Redescription of the first zoea of Latreutes laminirostris (Decapoda: Caridea: Hippolytidae). J. Nat. Sci., Silla Univ., 13: 43-47.

Yang, H.J. and W. Kim, 2006a. A new record of Lysmata amboinensis (De Man) (Decapoda: Hippolytidae) from Jeju-do Island, Korea. J. Fish. Sci. Technol., 9: 118-122.

Yang, H.J. and W. Kim, 2006b. First zoeas of Eualus leptognathus (Decapoda, Caridea, Hippolytidae) hatched in the laboratory. Korean J. Syst. Zool., 22: 117-120.

Received October 15, 2010 Accepted November 12, 2010 